\title{
Font games in typography education: Typewar
}

\author{
Hatice Öz Pektaş ${ }^{1 *}$ \\ ${ }^{1}$ Nişantaşı Universitesi, Commonication Design Departmnent, 34398 Istanbul, Turkey
}

\begin{abstract}
Typography is an area of expertise that focuses on artistic and design-based features and production technologies of all printed scripts. Although typography is an important element of many design branches, it is primarily one of the basic courses of Communication Design, Visual Communication Design, and Graphic Design departments. Current education methods are outdated and boring for the young target audience who got used to a lifestyle full of computers and mobile devices. Digital games are important means used in educational environments thanks to computer technologies. In 2017-2018 Academic Year's Fall Semester, 20 students from Graphic Design and Communication Design Departments who took Typography I course was made to play "typewar" game and the results of the games were recorded and the success of the students in recognizing the writing types in this game was measured. The typewar game was preferred in order to teach students "the anatomical structures of the whole alphabet by introducing serif and non-serif fonts" as a purpose of the course. In the research, it was observed that there was a difference in the number of the font types that students can remember and distinguish between classical methods and typewar game. In the survey made after the game, students' opinion on the use of games in typography education was taken.
\end{abstract}

\section{Introduction}

To recognize the serif and non-serif fonts and to learn the whole anatomical structure of alphabet.

\subsection{Quoted fonts}

Quoted fonts are still widely used in books and encyclopedias. While we encounter with them rarely, they are frequently used in blog posts and they continue to make the digital world more beautiful both for readability and stylish designs.

The greatest benefit that they provide is that they are understandable and not eyestraining. The dentations that are added to the letter ends make them clearer and the eyes spend much less time to see a letter and deliver it to the brain and the brain gets tired much latter accordingly $[6,7]$.

\footnotetext{
* Corresponding author: hatice.pektas@nisantasi.edu.tr
} 


\subsection{Sans serif fonts}

Their main feature is that they do not have any quote, cedilla, notch and dentation and they provide top level aesthetics. For the considerably long letters, the reader feels that the letters converge as it concentrates and the eyes becomes tired swiftly. Such fonts are mostly used for short materials such as signs, titles, short children's books and places with aesthetic concerns $[3,4]$.

\subsection{Problem}

The term "typography" was first used to describe Johan Gutenberg's metal letters. Today, it is regarded as a field of expertise dealing with the artistic and design-based features and production technologies of all printed scripts. Typography is the visual and functional editing made on a page specified by the elements needed for letters, words, and spacing. Although typography is an important element of many design branches, it is primarily one of the basic courses of Communication Design, Visual Communication Design, and Graphic Design departments. At the undergraduate level, typography education requires a theoretical and practical curriculum. $[3,4,6,7]$.

\subsection{Purpose}

The objective of this research is to emphasize that learning through game contributes to university education. It further aims to observe and evaluate the impact of the different games in the typography lectures in the department of graphic design on the learning.

\subsection{Importance of research}

The content of Typography I course includes: The development of alphabet; face types; right typeface selection; spacing, punctuation marks and problems in text editing and solutions; rules of script use.

Students who took the class are expected to be able to these: 1 . To have a good grasp of Basic Typography concepts and to express them. 2. To recognize the serif and non-serif fonts and to learn the whole anatomical structure of alphabet. 3. To be able to distinguish the readability of texts after spacing. 4. To keep the script readable and to use it properly. 5. To be able to recognize the fonts and their families quickly with experimental studies. 6 . To be able to see the result of right font selection in design.

Typewar game was preferred in order to teach students "the anatomical structures of the whole alphabet by introducing serif and non-serif fonts" as a purpose of the course. It is very crucial for a communication designer to distinguish between font types. For this reason, Typewar is a fun game of font identification and learning for both beginners and experienced designers. Typewar was developed by the Massive Overrated company and it is available both on mobile and web. In the game, two different font type is shown on the screen and you are expected to name them. After selecting the font type regarding your guess, right answer and the score screen is shown [8, 9, 10, 11, 12].

While playing, you can see your accumulated score on the bottom of the screen. If you guess right your score goes up and if guess wrong it goes down. As you level up, new font types are shown. The longer you play Typewar, the more font types are unlocked and difficulty increases. Although the game gets more difficult as new font types are added, 
there are many ways to choose the right answer. In Typewar, if you choose the right font type, your score goes up and if you choose the wrong answer your score goes down. There is no time limit, beginning or ending in the game. $[8,9,10,11,12]$.

\section{Research methods}

In 2017-2018 Academic Year's Fall Semester, 20 students from Graphic Design and Communication Design Departments who took Typography I course was made to play "typewar" game and the results of the games were recorded and the success of the students in recognizing the writing types in this game was measured..

In the research, students were first shown the names of different font types and were taught their distinguishing features with examples. Then, they were asked to tell the names of font types they remember and recognize some of the font types in the examples shown in the class.

\subsection{Research group}

We have selected the students of Department of Graphic Design, Faculty of Art and Design in Nisantasi University as a research group.

\subsection{Sample group}

Selected research group represents the university students at graphic design department, having an age range of 18-25.

\subsection{Data gathering system}

We have used the game screen of the students as a data collection tool. We have interpreted the views on the screenshots and asked for the students who play the game about their opinions.

\subsection{Data Analysis}

It was observed that the number of font types they can remember and distinguish after the classical method and after the typewar game was different. In the survey made after the game, students' opinion on the use of games in typography education was taken.

\section{Findings}

As a result of the research and survey, it can be said that the use of typewear game for educational purpose increases the students' interest in the course and contributes to the learning of typography. 


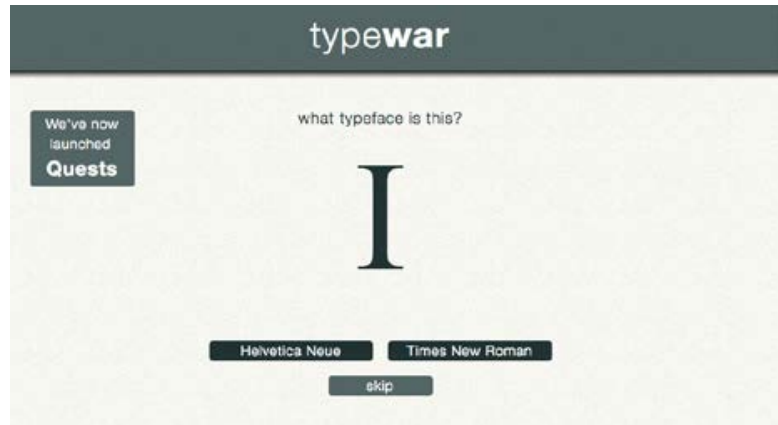

Fig. 1. "I" Times New Roman or Helvetica Neue

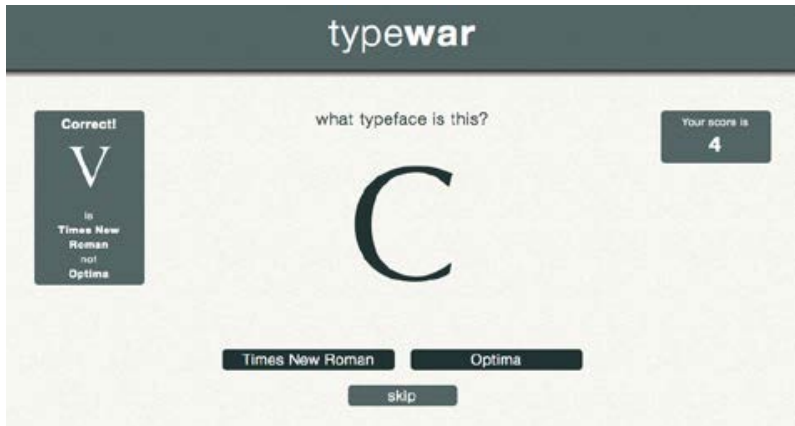

Fig. 2. "C" Times New Roman or Optima

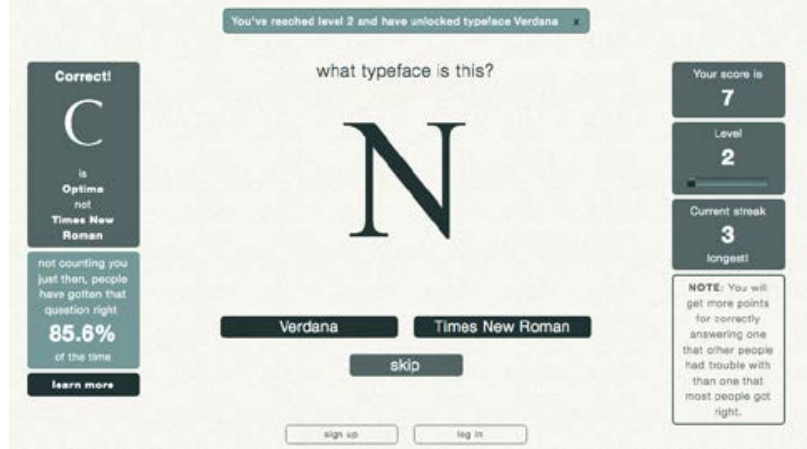

Fig. 3. "N" Times New Roman or Verdana

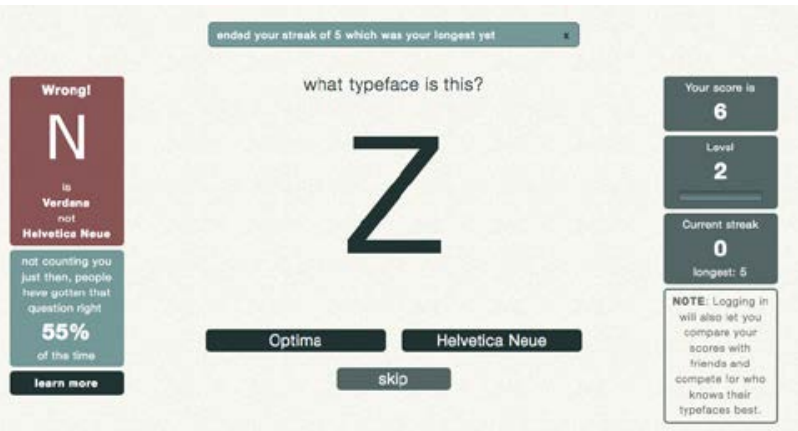

Fig. 4. "Z" Helvetica Neue or Optima 


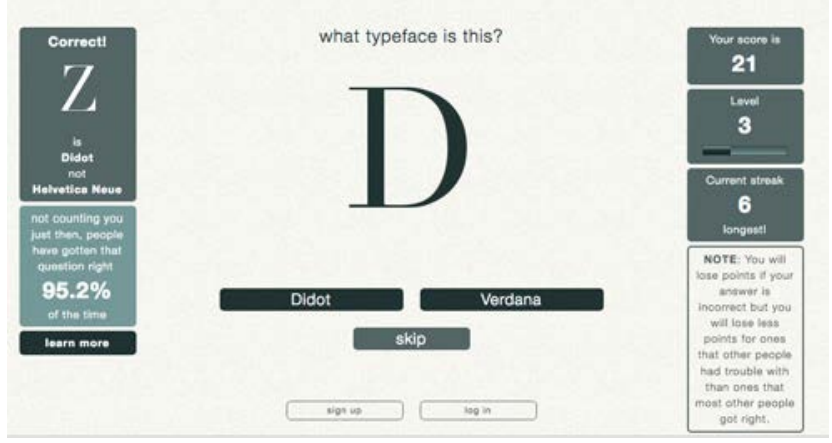

Fig. 5. "D" Didot or Verdana

\section{Discussion}

Digital game based learning aims to teach students through educational computer games. The characteristics of the digital game based learning is an intentional education by students. They can be any form of educational computer games like normal computer games: strategy, action and etc. For each content, students can be offered a wide range of different learning methods through many types of game. Educational computer games provide hidden learning. In other words, the student plays the computer game with a joy and realizes that he has learned when the game is over. Educational computer games can be combined with other learning methods and provide complete learning $[1,2,5]$.

\section{Appreciations}

As a result of the research and survey, it can be said that the use of typewar game for educational purpose increases the students' interest in the course and contributes to the learning of typography.

\section{References}

1. Binark, M., Bayraktutan Sütçü, G., Barış Fidaner, Işık., Dijital Oyun Rehberi, Kalkedon Yayınları (2010)

2. Binark, M., Dijital Oyun, Kalkedon Yayınları (2008)

3. Harris, P., Ambrose, Görsel Tipografi Sözlüğü, Literatür Yayıncılık (2012)

4. Harris, P., Ambrose, G., Grafik Tasarımda Tipografi, Literatür Yayıncılık (2014)

5. Prensky, Marc “Digital Natives, Digital Immigrants” On the Horizon (MCB University Press, Vol. 9 No. 5, October 2001)

6. Sarıkavak, N., Tipografinin Temelleri, Doruk Yayınları (1997)

7. Sarıkavak, N., Çağdaş Tipografinin Temelleri, Seçkin Yayıncılık (2014)

8. www.typewar.com (01.07.2018)

9. "Typewar and The Font Game for iPhone" https://www.macworld.com/article/1150829/typewar_thefontgame.html (Date of acces: 01.07.2018)

10. "Typeface Clustering Based on Typewar" https://eldarion.com/blog/2010/02/02/typeface-clustering-based-typewar/ (Date of acces: 01.07.2018) 
11. "Typewar: Points and Levels" https://eldarion.com/blog/2010/01/20/typewar-pointsand-levels/ (Date of acces: 01.07.2018)

12. "Best Typography Games for Designers” https://medium.com/@order_group/best-typegames-for-designers-e51f17bbe464" (Date of acces: 01.07.2018) 